\title{
Diversity and biosynthetic potential of culturable aerobic heterotrophic bacteria isolated from Magura Cave, Bulgaria
}

\author{
Iva Tomova ${ }^{1}$, Irina Lazarkevich ${ }^{1}$, Anna Tomova ${ }^{1}$, Margarita Kambourova ${ }^{1}$, \\ and Evgenia Vasileva-Tonkova ${ }^{1^{*}}$ \\ ${ }^{1}$ Bulgarian Academy of Sciences, The Stephan Angeloff Institute of Microbiology, Acad. G. Bonchev Str., Bl. 26,1113 Sofia, Bulgaria
}

\begin{abstract}
Biocapacity of bacteria inhabiting karstic caves to produce valuable biologically active compounds is still slightly investigated. A total of 46 culturable heterotrophic bacteria were isolated under aerobic conditions from the Gallery with pre-historical drawings in Magura Cave, Bulgaria. Phylogenetic analysis revealed that most of bacterial isolates affiliated with Proteobacteria (63\%), followed by Actinobacteria (10.9\%), Bacteroidetes (10.9\%), and Firmicutes (6.5\%). A strong domination of Gram-negative bacteria (total $81 \%$ ) belonging to nine genera: Serratia, Pseudomonas, Enterobacter, Sphingobacterium, Stenotrophomonas, Commamonas, Acinetobacter, Obesumbacterium, and Myroides, was observed. Gram-positive isolates were represented by the genera Bacillus, Arthrobacter, and Micrococcus. One isolate showed a significant phylogenetic distance to the closest neighbor and could represent a novel species. Heterotrophic bacterial isolates from Magura Cave were investigated for hydrolytic enzymes production, antimicrobial and hemolytic activity. Predominance of producers of protease $(87 \%)$, followed by xanthan lyase $(64 \%)$, lipase $(40 \%)$, $\beta$-glycosidase $(40 \%)$, and phytase $(21 \%)$ was observed. Over $75 \%$ of the isolates demonstrated antimicrobial and hemolytic activity. The results suggest that heterotrophic bacteria isolated from Magura Cave could be a valuable source of industrially relevant psychrotolerant enzymes and bioactive metabolites. This study is a first report on the taxonomic composition and biological activity of culturable bacteria inhabiting a cave in Bulgaria.
\end{abstract}

Keywords: caves; Magura Cave; culturable bacteria; 16S rDNA; enzyme production; antimicrobial activity; hemolytic activity

Received 7 June 2012; Revised 3 October 2012; Accepted 1 December 2012

Citation: Tomova I., Lazarkevich I., Tomova A., Kambourova M. and Vasileva-Tonkova E., 2013. Diversity and biosynthetic potential of culturable aerobic heterotrophic bacteria isolated from Magura Cave, Bulgaria. International Journal of Speleology, 42 (1), 65-76. Tampa, FL (USA) ISSN 0392-6672 http://dx.doi.org/10.5038/1827-806X.42.1.8

\section{INTRODUCTION}

Caves are nutrient-poor, dark ecosystems with relatively constant low temperature and high relative humidity in the dark zone deep within the cave. Although providing extreme conditions for life, the caves are colonized by diverse psychrophilic (cold-loving) and psychrotolerant (cold-adapted) microorganisms that are able to grow in these environments (Schabereiter-Gurtner et al., 2002a; Barton \& Northup, 2007). Processes of disintegration and formation of cave saltpeter, mineral oxides accumulations, coloration, and moonmilk deposits in many karstic caves have been linked with microbial activity (Castanier et al., 2000).

At present, most of the well-known and visited caves containing valuable pre-historical paintings are affected by progressive microbial colonization and biodeterioration, and the control, treatment, and preservation of these specific environments is a serious worldwide problem (Cañaveras et al., 2001; Allemand \& Bahn, 2005; Fox, 2008). Today, most caves containing such paintings are closed off to visitors as a conservative measure to prevent further degradation of valuable cultural heritage sites. The literature on microbial communities in subterranean environments is mainly restricted to caves found in Spain, Italy, France, Romania, and the USA. A long-term microbiological study of the cave microflora is being conducted in Altamira Cave (Spain) and Lascaux Cave (France), both containing Paleolithic paintings (Schabereiter-Gurtner et al., 2002a; Bastian et al., 2009).

Despite their archaeological importance, our knowledge on the microbiology of caves is still scanty and incomplete. Although geomicrobiological environmental investigations are widely presented, a 
significant increase in biospeleological research was observed within the last two decades (Urzi et al., 2010). Caves can be considered extreme environments for life providing ecological niches for highly specialized microorganisms (Schabereiter-Gurtner et al., 2002b). These microorganisms, called extremophiles, produce enzymes that are functional under extreme conditions (Van den Burg, 2003). Although many papers have been published on isolation of psychrophilic and psychrotolerant bacteria from cold environments and their enzymatic activities, caves are still under-explored as an object for such investigations. Our knowledge of cave microbial diversity is limited; therefore, great potential exists to find novel microorganisms in caves (Engel, 2010). One of the essential mechanisms for adaptation of microorganisms to cold environments is the activity of their enzymes at low temperatures. In recent years, there is an increased interest in coldadapted microorganisms and their enzymes because of their great biotechnological potential, offering numerous economic and ecological advantages. Because of the unique properties, cold-adapted enzymes could be extremely useful in different biotechnological fields, for example, in the detergent and food industry, biotransformation, environmental bioremediation, molecular biology, diagnostics, biosensors and bioreporters (Russell, 1998; Gerday et al., 2000; Cabeza et al., 2011; Cavicchioli et al., 2011).

Karstic Magura Cave is situated near the village of Rabisha, North-West Bulgaria. Being a monument of culture and a tourist destination, it is one of the biggest and the most beautiful caves in Bulgaria. In one of the Galleries unique prehistorical drawings were discovered that represent carvings into the stone filled with bat guano (Fig. 1). Ancient drawings are multi-layered, dating back from the Late Neolithic and Eneolithic Ages, to the the early Bronze Age, and are unique for the Balkan Peninsula (Stoytchev, 1994; 1995). They represent different religous events and feasts in separate groups. The Solar calendar from the Late Neolith is the earliest solar calendar discovered in Europe; it depicts five festivals and 366 days and may have represented a shrine for the prehistoric settlement. As a result, Magura Cave was placed on the tentative list for consideration as a World Heritage Site by UNESCO in 1984. The cave has been opened for visitors only for three years; however, this resulted in changes in cave's microclimate due mainly to the presence of artificial light and emitted heat, and in enhanced deterioration of many of the drawings by vandal effects. That is why, in 2008 the so called Gallery with the drawing was closed to the public as a conservative measure to preserve the valuable drawings.

No studies have been undertaken until now for isolation and cultivation of microorganisms inhabiting Bulgarian caves and investigation of their biosynthetic capacity. In this study, culturable aerobic heterotrophic bacteria inhabiting the Gallery with the drawings in Magura Cave were isolated and characterized, and their biosynthetic abilities were investigated in aim to identify promising psychrotolerant bacterial strains, producers of industrially relevant enzymes and antimicrobial compounds.
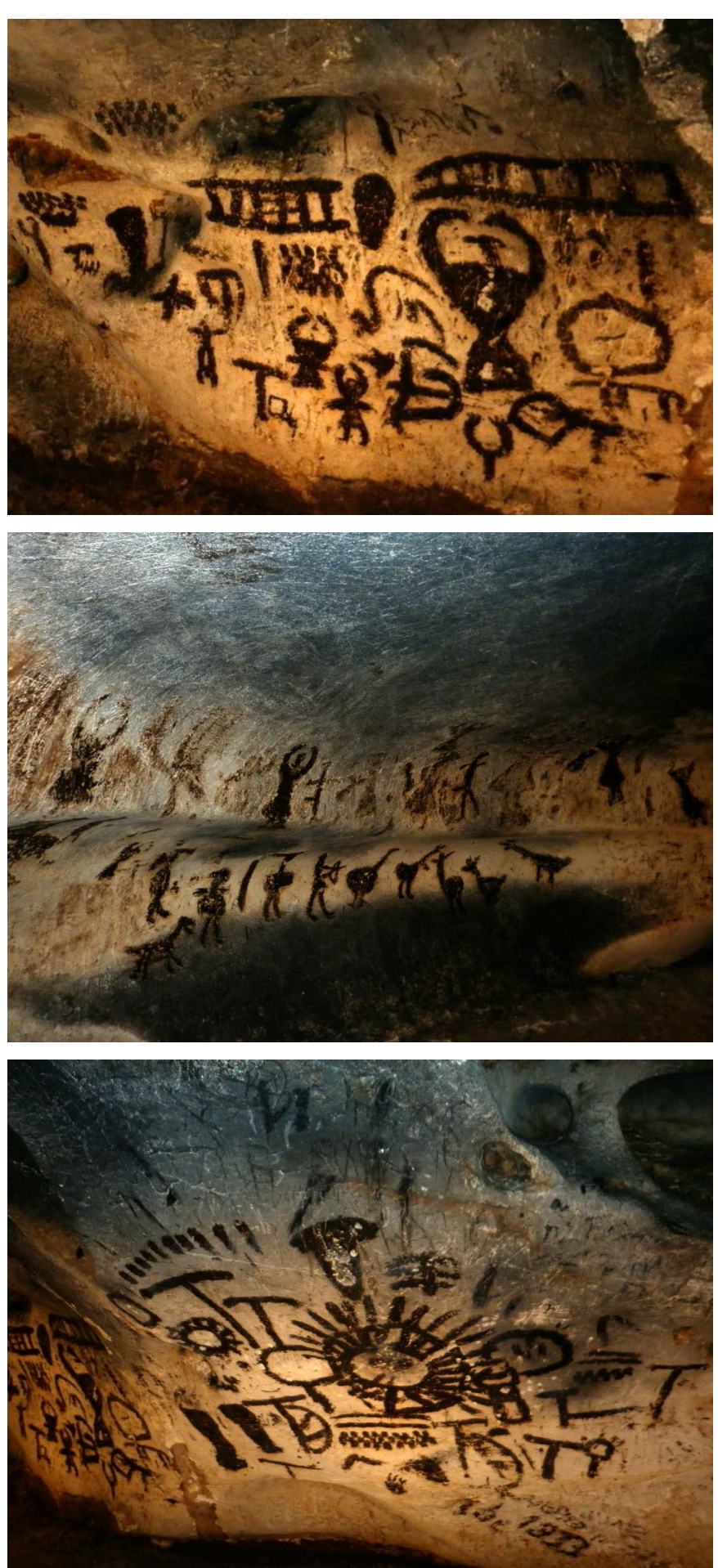

Fig. 1. Rock wall drawings in the gallery with the drawings in Magura Cave.

\section{MATERIALS AND METHODS}

\section{Sampling site}

Geological analysis showed that the formation of Magura Cave has started 15 million years ago on a calcareous hill (at $461 \mathrm{~m}$ above the sea level) composed of a succession of subhorizontal decimeter-thickbeds of Cretaceous calcarenitic limestones. Magura Cave consists of a main gallery and three side branches with a current overall length of approximately 3,000 m (http://www.magura-cave.com/1024x768/eng/the cave.htm). The northern end of "the Landslip" is connected to the alley with the drawings. On its main axis, the corridor measures $240 \mathrm{~m}$ in length and covers $3,750 \mathrm{~m}^{2}$ in 
area. Its maximum height is $24 \mathrm{~m}$. The unique cave drawings are situated in this corridor. The isolated location of the Gallery with the drawings and its longness contribute to the maintenance of a relatively constant temperature of around $12{ }^{\circ} \mathrm{C}$ and relative humidity above $90 \%$.

\section{Sample collection}

Samples were collected in the beginning of April 2011 from the Gallery with the drawings in Magura Cave. Samples of about 30 to 50 g each were collected in sterile glass jars by gently scrapping by sterile scalpels of rock walls (in depth up to $1 \mathrm{~mm}$ ) in the vicinity of separated drawings at a level $30-50 \mathrm{~cm}$ above the floor. A control sample was also collected from rock wall surfaces of a side area of the Gallery without drawings. In parallel, wall samples, sediment samples from the floor (containing bat guano), and water samples were also collected by the research team from Sofia University. Collected samples were transferred to the laboratory in a thermostat bag, kept in a refrigerator for about $18 \mathrm{~h}$ and used as inocula for enrichment.

\section{Isolation and growth of heterotrophic bacteria}

Enrichment for isolation of bacterial cultures was performed for each sample (about $10 \mathrm{~g}$ ) aerobically at $14{ }^{\circ} \mathrm{C}$ during 10 days including two transfers, in 100-ml Erlenmeyer flasks containing 10-ml sterile nutrient broth (NB). After two transfers, a loopful of each inoculum source was streaked onto nutrient agar (NA) plates. The plates were then incubated at $14{ }^{\circ} \mathrm{C}$ and monitored at $24 \mathrm{~h}$ intervals for a period of a week in order to isolate a variety of growing bacteria. Different types of colonies were picked after incubation and stroked onto NA plates to obtain pure cultures. All isolates were maintained by monthly transfers onto slants containing NA and stored at $4{ }^{\circ} \mathrm{C}$. The strains were stored also at $-80{ }^{\circ} \mathrm{C}$ in $\mathrm{NB}$ supplemented with $30 \%(\mathrm{v} / \mathrm{v})$ glycerol.

Growth of bacteria isolated from Magura Cave was followed at temperatures of $4{ }^{\circ} \mathrm{C}, 10^{\circ} \mathrm{C}, 20^{\circ} \mathrm{C}, 28^{\circ} \mathrm{C}$, and $40{ }^{\circ} \mathrm{C}$. Isolates were cultivated at the indicated temperatures in test-tubes containing NB with added aliquots of each bacterial inoculum, and the growth was monitored until the stationary phase by measuring the optical density at $570 \mathrm{~nm}\left(\mathrm{OD}_{570}\right)$.

\section{S rDNA amplification and restriction analysis}

The isolates were subjected to $16 \mathrm{~S}$ rDNA analysis to determine their phylogenetic affiliation. Genomic DNA from a broth culture of the strains was isolated using GenElute Bacterial Genomic DNA kit (Sigma). The small-subunit rRNA gene was amplified from the extracted DNA using universal bacterial primers specific to $16 \mathrm{~S}$ rRNA gene, primer $8 \mathrm{~F}$ and primer 1492R (Weisburg et al., 1991). The PCR reaction mixture $(20 \mu l)$ contained: 1 to $10 \mathrm{ng}$ of template, Prime Taq Premix 2x (GENET BIO) containing 1 U/ 10 $\mu 1$ DNA Polymerase, $20 \mathrm{mM}$ Tris-HCl, $80 \mathrm{mM} \mathrm{KCl,} 4$ $\mathrm{mM} \mathrm{MgCl}_{2}$, enzyme stabilizer, sample, loading dye, $\mathrm{pH}$ 9.0, $0.5 \mathrm{mM}$ of each dATP, dCTP, dGTP, dTTP, and $400 \mathrm{nM}$ of each primer. The reaction mixture was incubated in a T100 Thermal Cycler (BIORAD) for an initial denaturation at $94{ }^{\circ} \mathrm{C}$ for $5 \mathrm{~min}$ followed by 30 cycles of $94^{\circ} \mathrm{C}$ for $30 \mathrm{~s}, 55^{\circ} \mathrm{C}$ for 30 $\mathrm{s}$, and $72{ }^{\circ} \mathrm{C}$ for $60 \mathrm{~s}$, then a final extension step at $72{ }^{\circ} \mathrm{C}$ for $5 \mathrm{~min}$. The amplified 16S rRNA genes of the isolates were subjected to two separate RFLP analyses, using four base pairs restriction enzymes in order to maximize the RFLP resolution. Seven $\mu 1$ of the amplified PCR products were separately digested with $5 \mathrm{U}$ of restriction endonucleases $M s p I$ and HaeIII (Fermentas) in a final volume of $10 \mu \mathrm{l}$ for $2 \mathrm{~h}$ at $37^{\circ} \mathrm{C}$. Isolates with identical RFLP profiles were considered to be phylogenetically identical. Representatives of each RFLP pattern group were chosen for sequencing (total 24 strains).

The full sequence (8-1,492 nt; $E$. coli numbering) of the 16S rRNA gene of the strains was determined with Applied Biosystems model 373A DNA sequencer by using the ABI PRISM cycle sequencing kit (Macrogen, South Korea). DNA sequence analyses were performed using BLASTn (Altschul et al., 1990) and Ribosomal Database Project resources (Maidak et al., 1994) to determine their close relatives and approximate phylogenetic affiliations. Multiple sequence alignments were obtained using CLUSTALX (Thompson et al., 1997). The phylogenetic analysis was performed using the program PAUP* Version 4.0b10 (Swofford, 2002). The sequence that showed more than $3 \%$ divergence with the closest phylogenetic neighbor was submitted to a database under accession number HE663456. All other sequences were not deposited due to the lack of novelty and were used for phylogenetic identification of the isolates.

\section{Screening for enzyme and hemolytic activities}

Hydrolytic enzyme production by bacterial isolates from Magura Cave was determined qualitatively by the agar diffusion method. Petri plates contained basal mineral medium with $1.5 \%$ agar and a substrate specific for the corresponding activity. Basal mineral medium ( $\mathrm{pH} 7.0$ ) contained (\%): $\mathrm{KH}_{2} \mathrm{PO}_{4} 0.1,\left(\mathrm{NH}_{4}\right)_{2} \mathrm{SO}_{4}$ $0.5, \mathrm{MgSO}_{4} .7 \mathrm{H}_{2} \mathrm{O} 0.01$, and $\mathrm{NaCl} 0.01$. A loop of each of $24 \mathrm{~h}$ pure bacterial culture grown on NA was spread via a needle on the test media. The plates were then incubated in the dark at $28 \pm 2{ }^{\circ} \mathrm{C}$ for 4 to 10 days depending on the activity tested. Two replicates were carried out for each sample. The cultures that showed growth, clearing zones, or color-diffusion zones on respective specific media were considered as positive cultures. Extracellular protease production was determined by using $30 \%(\mathrm{v} / \mathrm{v})$ skim-milk or $1 \%$ $(\mathrm{w} / \mathrm{v})$ gelatin; a clear zone around the colony indicated presence of proteolytic activity (PrA). The a-amylase activity (AmA) was determined by using $1 \%(\mathrm{w} / \mathrm{v})$ insoluble starch and detected as a clear zone around the colony (Dhawale et al., 1982). Ribonuclease (RNAse) or desoxiribonuclease (DNAse) activities were detected in test agars containing $0.5 \%(\mathrm{w} / \mathrm{v})$ RNA or DNA, respectively. Growth with RNAse/DNAse production appeared surrounded by a clear halo as a result of the degradation of RNA/DNA to soluble nucleotides, which were not precipitated by the added $1 \mathrm{~N}$ hydrochloric acid. Lipolytic activity (LipA) 
was tested by hydrolysis of $1 \%$ Tween 80 in a basal agar medium amended with $0.01 \% \mathrm{CaCl}_{2} \cdot 2 \mathrm{H}_{2} \mathrm{O}$ and was seen as either a visible precipitate of the calcium chloride-lipid complex around a colony, or as a clearing zone around a colony due to complete degradation of the salt complex (Smilbert, 1994). The strains were screened for cellulase activity in agar medium with $2 \%$ (w/v) CMC (Carboxymethyl cellulose) as a substrate. The plates were incubated and stained with Congo red dye and destained (Teather \& Wood, 1982). The positive cellulase activity was shown as a presence of yellow hallo against red background. Urease activity was tested on urea agar plates with $2 \%$ urea and phenol red and detected as a formation of a pink-colored clear zone around the colonies (MacFaddin, 2000). Phytase activity (PhyA) was determined after growth of the strains up to 10 days on agar plates containing phosphate-depleted basal medium supplemented with $0.5 \%(\mathrm{w} / \mathrm{v})$ sodium phytate (Sigma, USA) as a substrate following procedure described by Bae et al. (1999). The $\beta$-glucosidase activity ( $\beta$-gluA) was evaluated on a selective medium containing $0.4 \%$ arbutin (hydroquinone $\beta$-d-glucopyranoside) (Santa Cruz, USA); a positive result was indicated by the growth and dark brown halo around the colonies (Mendes Ferreira et al., 2001). Polygalacturonase (PGAse) activity was detected by the degradation of polygalacturonic acid using Ruthenium red plate assay (Cotty et al., 1990). Xanthan lyase activity was detected by the growth of the strains in liquid basal mineral medium containing $0.2 \%(\mathrm{w} / \mathrm{v})$ xanthan as a sole carbon source.

Extracellular hemolytic activity was tested by dropping of $0.1 \mathrm{ml}$ cell suspensions of each bacterial culture (grown on NB for 20-h) into wells on blood agar plates. After incubation for $48 \mathrm{~h}$ to $72 \mathrm{~h}$ at $28 \pm 2{ }^{\circ} \mathrm{C}$, the zones of hemolysis of erythrocytes were measured.

\section{Screening for antimicrobial activity}

Bacterial isolates from Magura Cave were tested for their ability to inhibit the growth of four indicator cultures: Bacillus subtilis ATCC 6633, Pseudomonas aeruginosa NBIMCC 1390 (National Bank of Industrial Microorganisms and Cell Cultures, Bulgaria; http:// www.nbimcc.org/en/about.htm), the phytopathogenic bacterial strain Xanthomonas oryzae, causing bacterial blight of rice, and the yeast Rhodotorula mucilaginosa 6526 (formerly Rhodotorula rubra). Cave bacterial isolates were grown on NB for $20 \mathrm{~h}$ (in exponential growth phase) before detection of an antimicrobial activity by the agar well diffusion method. Indicator cultures were spread on the agar media, followed by hole-punches (6-mm in diameter) that were filled with $0.1 \mathrm{ml}$ cell suspension of each cave organism. After overnight incubation at $28 \pm 2{ }^{\circ} \mathrm{C}$, clear zones (halos) were recorded as a zone diameter (in millimeters) around the wells minus 6-mm diameter of the well.

\section{RESULTS}

\section{Isolation and identification of culturable bacteria from Magura Cave}

A total of 46 aerobic heterotrophic bacterial strains were isolated from the Gallery with the drawings in
Magura Cave (Table 1). Fourteen bacterial strains were recovered from the painted surfaces, 25 from adjacent rock wall surfaces, 5 from bat guano (in sediment samples), and 2 from water samples. Strains No 1-25 were isolated in Faculty of Biology at Sofia University; other strains were isolated in the Institute of Microbiology-BAS and marked shortly as IM. After amplification and restriction of the $16 \mathrm{~S}$ rRNA gene for each isolate their restriction profiles were compared and the strains were distributed into eighteen groups. Representatives of four phylogenetic groups: Proteobacteria, Actinobacteria, Firmicutes, and Bacteroidetes were identified with a strong Proteobacteria domination (Fig. 2). After sequencing and phylogenetic analysis, a strong domination of Gram-negative heterotrophic bacteria was established (81\%), belonging to nine genera: Serratia, Pseudomonas, Enterobacter, Sphingobacterium, Stenotrophomonas, Commamonas, Acinetobacter, Obesumbacterium, and Myroides, with predominance of Serratia and Pseudomonas strains. Gram-positive isolates $(19 \%)$ were representatives of three genera: Bacillus, Arthrobacter, and Micrococcus. Isolate IM13 was determined to share $94 \%$ sequence similarity of its $16 \mathrm{~S}$ rRNA gene to the nearest phylogenetic relative of the genus Myroides and may represent a novel species.

\section{Growth patterns of bacterial isolates}

Growth of the bacterial isolates from Magura Cave was followed at temperatures of $4{ }^{\circ} \mathrm{C}, 10^{\circ} \mathrm{C}, 20^{\circ} \mathrm{C}, 28$ ${ }^{\circ} \mathrm{C}$, and $40{ }^{\circ} \mathrm{C}$, and values of $\mathrm{OD}_{570}$ in the beginning of stationary phase were compared. The growth of Magura Cave isolates at different temperatures is shown in Table 1 and Fig. 3. The majority of isolates (33 strains) were psychrotolerant determined by their ability to grow at both $4{ }^{\circ} \mathrm{C}$ (although too slow) and above $20{ }^{\circ} \mathrm{C}$, highest growth rate observed at temperatures between 20 and $30{ }^{\circ} \mathrm{C}$, and may have upper limits as high as $40{ }^{\circ} \mathrm{C}$ (Morita, 1975). Thirteen strains appear to be mesophilic, for which the growth at $40{ }^{\circ} \mathrm{C}$ was from 2.5 to 9 times higher (depending on the strain) than the growth determined at $4{ }^{\circ} \mathrm{C}$.

\section{Hydrolytic enzymes and hemolytic activity}

Heterotrophic bacteria isolated from Magura Cave were tested for hydrolytic enzymes activity on

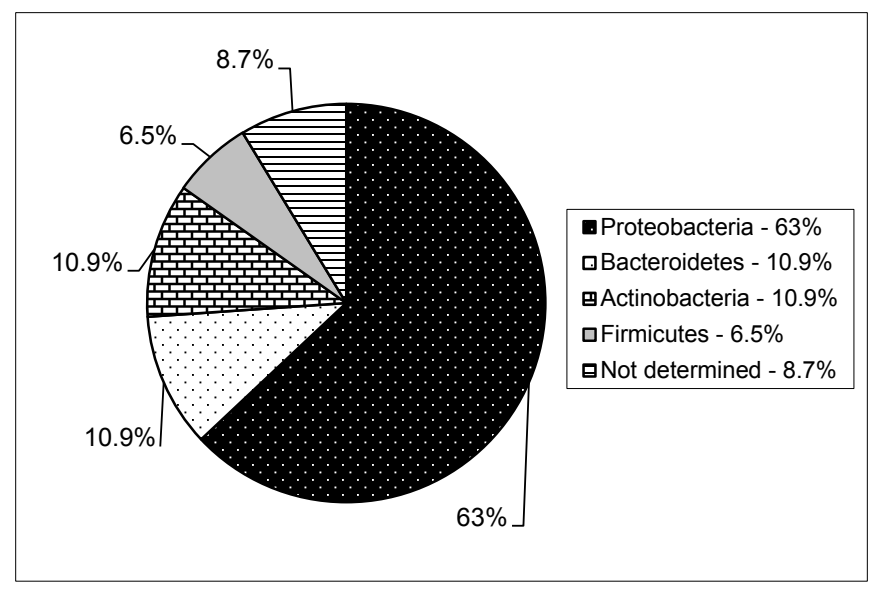

Fig. 2. Phyla distribution of heterotrophic bacteria isolated from the Gallery with the drawings in Magura Cave. 
Table 1. Properties of heterotrophic bacteria recovered from the Gallery with the drawings in Magura Cave.

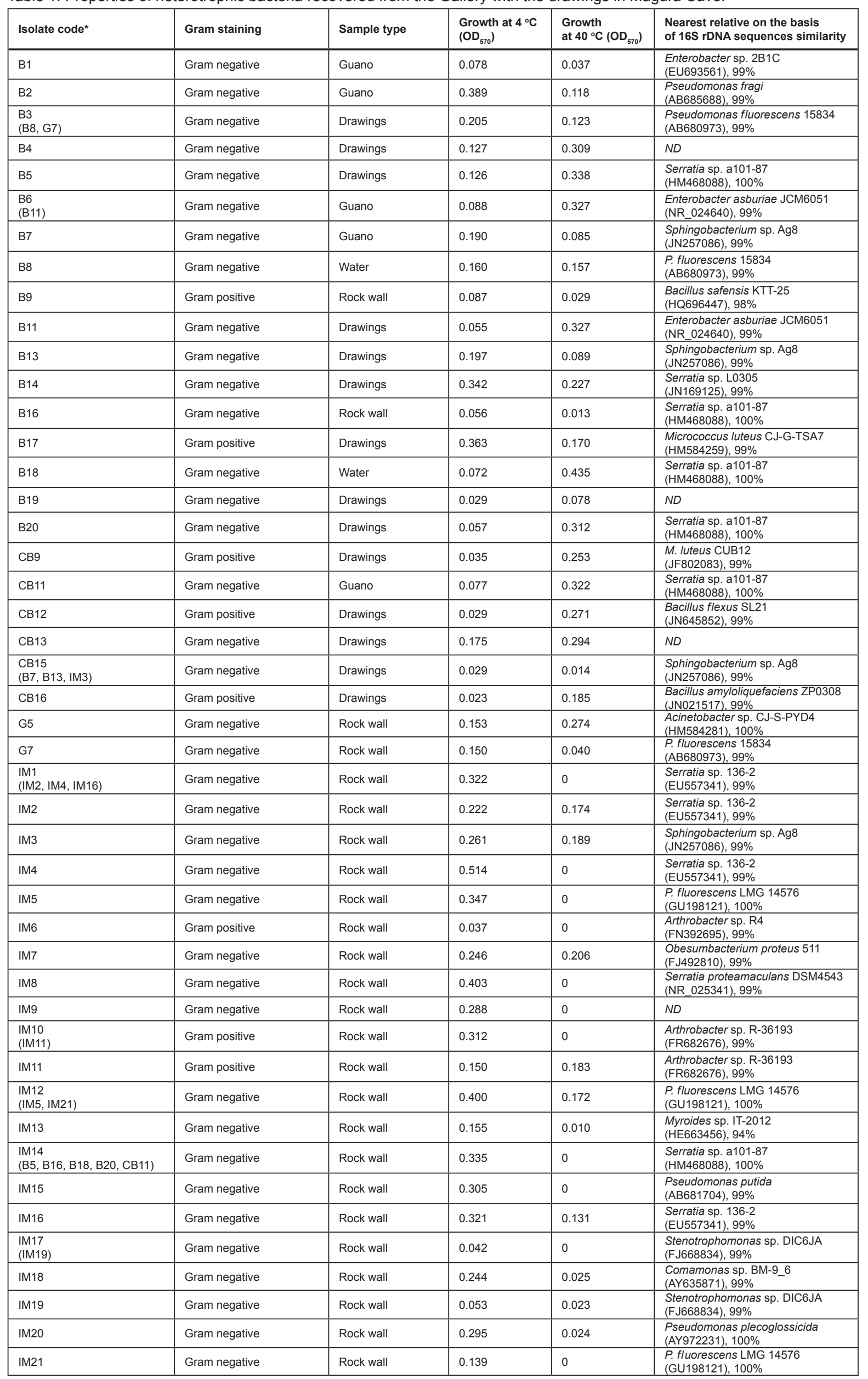

$N D$, not determined.

${ }^{*}$, strains in the brackets were referred to the same restriction group and were non-sequenced. 


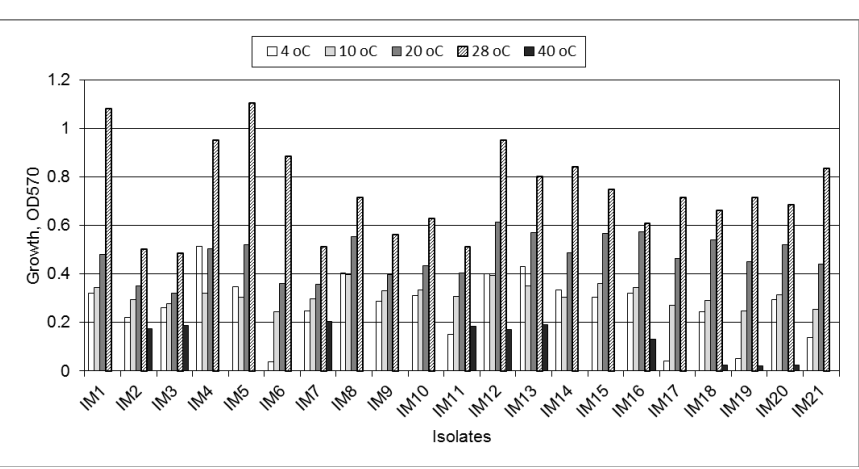

Fig. 3. Growth of bacterial isolates (IM1-21) from Magura Cave at different temperatures

agar medium using specific substrates. Isolates were screened for production of the main hydrolytic enzymes (proteases, lipases, amylases, nucleases) as well as for production of some enzymes with potential biotechnological application, such as phytase, xanthan lyase, polygalacturonase, and $\beta$-glucosidase. We found that the most often observed hydrolytic enzymes were proteases and xanthan lyases than the other enzymes (Table 2). Up to $87 \%$ of the isolates showed proteolytic activity, and skim milk appeared to be more favorable substrate than gelatin $(68 \%$ and $51 \%$ of isolates, respectively). About $64 \%$ of isolates were able to grow on xanthan mineral medium indicating presence of xanthan lyase activity; $40 \%$ of isolates showed lipase and $\beta$-glycosidase activity, and $21 \%$ - phytase activity. Polygalacturonic acid was hydrolyzed only by two strains, IM14 and IM15. RNAse and amylase activity were detected only for a strain CB16. No hydrolysis of DNA and CMC was observed.

It was found that about $76 \%$ of the cave isolates exhibited hemolytic activity after testing on blood agar plates (Table 3). Among them, 40\% showed weak hemolytic zone up to $1.5 \mathrm{~mm} ; 15 \%$ showed zone of 2-2.5 $\mathrm{mm}$, and $21 \%$ of the strains - zone of 3-4 mm.

\section{Antimicrobial activity}

It was established that about $50 \%$ of the isolates from Magura Cave exhibited inhibitory activity against $P$. aeruginosa and the yeast strain $R$. mucilaginosa (Table 3). A significant inhibition zone of $20-\mathrm{mm}$ was observed for isolate B3 (Pseudomonas fluorescens) against $P$. aeruginosa, and $16-\mathrm{mm}$ against $R$. mucilaginosa. Isolates IM15 (Pseudomonas sp.), IM16 (Serratia sp.), IM18 (Comamonas sp.), and IM20 (Pseudomonas plecoglossicida) inhibited significantly the growth of $B$. subtilis. About $15 \%$ of the strains exhibited antimicrobial activity against $X$. oryzae; the highest inhibition was achieved by isolates B7 (Sphingobacterium sp.), IM18 (Comamonas sp.), and IM20 (P. plecoglossicida) with a zone of inhibition of 10$\mathrm{mm}$ in diameter. Among isolates, IM16 (Serratia sp.), IM18 (Comamonas sp.), and IM20 (P. plecoglossicida) could be considered as the most active inhibiting the growth of all tested cultures.

\section{DISCUSSION}

This study demonstrates that surfaces of drawings and rock walls in the Gallery with the drawings in the karstic Magura Cave are inhabited by diverse heterotrophic bacteria. By using NA, we isolated 46 culturable aerobic heterotrophic bacteria referred to four phyla. The relatively low number of isolated bacteria could be due to using nutrient-rich media, which may restrict the growth of bacteria which may be better adapted to the oligotrophic conditions of the cave environment. The observed domination of Proteobacteria is in a good agreement with previous studies in Kartchner Caverns, Arizona (Ikner et al., 2007), which also reported Proteobacteria as the most abundant phylum and suggested that their presence is a consequence of increased organic input by cave visitors. Considerable input of organic matter in many caves supported the growth of different types of heterotrophic bacteria, led to changes in microclimate and increased microbial dispersal and colonization (Ikner et al., 2007; Bastian et al., 2009; Mulec et al., 2012). Bat guano appears to be the major source of organic matter in Magura Cave that could contribute in increasing the abundance of Proteobacteria in the Gallery with the drawings. The predominance of Serratia and especially Pseudomonas isolates in Magura Cave could be considered as an evidence of a high degree of contamination of surfaces, probably due to insects and bats feces (Jurado et al., 2010), or could be the result of using rich medium for isolation. Comparing the bacterial diversity in caves from Australia, China, Spain and USA, Zhou et al. (2007) have found that a general trend in caves is that Proteobacteria is the largest group, followed by Acidobacteria, Actinobacteria, and Firmicutes. The bacteria isolated from several Siberian karstic cavities have been identified as Pseudomonas, Arthrobacter, Bacillus, and coryneform bacteria (Khizhnyak et al., 2003). Chelius \& Moore (2004) have cultured Actinobacteria and Proteobacteria isolates from Wind Cave (USA), but have not recovered any Firmicutes. Bacterial communities in the cave Škocjanske Jame (Slovenia) contained Enterobacteriaceae and Vibrionaceae, low proportions of Gram-positive bacteria, and practically no culturable Actinobacteria (Gerič et al., 2004). Contrary to our findings for Magura Cave, Actinobacteria are a dominant group in heterotrophic bacterial communities in many caves (Groth \& Saiz-Jimenez, 1999). Most of the isolated Actinobacteria could be assigned to the genus Streptomyces in certain caves such as Grotta dei Cervi (Italy), Altamira and Tito Bustillo (Spain), and 19 karstic caves in Turkey (Groth et al., 1999, 2001; Yucel \& Yamac, 2010). The low number of isolated Actinobacteria from Magura Cave could be due to the use of nutrient agar/broth, which is not routinely used for their isolation. Three of the isolated strains from Magura Cave (IM6, IM10, and IM11) were representatives of the genus Arthrobacter. One isolate, IM13, belonging to the genus Myroides is a candidate for a new species (accession number HE663456) suggesting that Magura Cave could be a source of novel microorganisms.

Some of the species belonging to the genera, identified in Magura Cave: Pseudomonas, Bacillus, Sphingobacterium, Stenotrophomonas, Arthrobacter, 
Table 2. Extracellular enzyme activities of heterotrophic bacteria isolated from the Gallery with the drawings in Magura Cave.

\begin{tabular}{|c|c|c|c|c|c|c|c|c|c|c|c|c|c|}
\hline $\begin{array}{l}\text { Isolate } \\
\text { code }\end{array}$ & $\begin{array}{l}\text { Strains referred to the nearest } 16 \mathrm{~S} \\
\text { sequence identity }\end{array}$ & $\begin{array}{l}\text { PrA } \\
\text { skim-milk }\end{array}$ & $\begin{array}{l}\text { PrA } \\
\text { gelatin }\end{array}$ & $\begin{array}{l}\text { LipA } \\
\text { Tween } 80\end{array}$ & AmA & RNAse & DNAse & CMCase & Urease & PGAse & XanthA* & PhytA & $\beta$-gluA \\
\hline B1 & Enterobacter sp. 2B1C & - & - & ++ & - & - & - & - & - & - & ++ & - & - \\
\hline B2 & Pseudomonas fragi & ++ & ++ & - & - & - & - & - & - & - & ++ & ++ & - \\
\hline B3 & Pseudomonas fluorescens 15834 & +++ & +++ & + & - & - & - & - & - & - & + & + & \pm \\
\hline B5 & Serratia sp. & + & + & - & - & - & - & - & - & - & - & - & - \\
\hline B6 & Enterobacter asburiae JCM6051 & \pm & - & - & - & - & - & - & ++ & - & - & - & - \\
\hline B7 & Sphingobacterium sp. & \pm & \pm & - & - & - & - & - & - & - & + & - & - \\
\hline B8 & Pseudomonas sp. & ++ & - & - & - & - & - & - & ++ & - & ++ & - & - \\
\hline B9 & Bacillus safensis KTT-25 & +++ & +++ & - & - & - & - & - & - & - & + & - & \pm \\
\hline B13 & Sphingobacterium sp. & ++ & \pm & - & - & - & - & - & + & - & + & - & - \\
\hline B14 & Serratia sp. L0305 & + & +++ & ++ & - & - & - & - & ++ & - & ++ & + & + \\
\hline B16 & Serratia sp. & + & ++ & +++ & - & - & - & - & +++ & - & - & - & - \\
\hline B17 & Micrococcus luteus CJ-G-TSA7 & + & - & - & - & - & - & - & +++ & - & ++ & - & ++ \\
\hline B18 & Serratia sp. & - & - & \pm & - & - & - & - & - & - & ++ & - & - \\
\hline B19 & $N D$ & +++ & + & \pm & - & - & - & - & - & - & + & - & - \\
\hline B20 & Serratia sp. & - & ++ & + & - & - & - & - & - & - & - & + & + \\
\hline CB9 & Micrococcus luteus CUB12 & +++ & +++ & ++ & - & - & - & - & - & - & +++ & + & - \\
\hline CB11 & Serratia sp. & - & ++ & \pm & - & - & - & - & - & - & + & - & + \\
\hline CB12 & Bacillus flexus SL21 & +++ & - & - & - & - & - & - & - & - & ++ & - & - \\
\hline CB13 & $N D$ & ++ & - & + & - & - & - & - & - & - & ++ & - & - \\
\hline G5 & Acinetobacter sp. CJ-S-PYD4 & - & - & ++ & - & - & - & - & - & - & + & \pm & \pm \\
\hline G7 & Pseudomonas sp. & ++ & + & - & - & - & - & - & ++ & - & - & + & - \\
\hline IM1 & Serratia sp. 136-2 & +++ & \pm & + & - & - & - & - & - & - & - & - & + \\
\hline IM2 & Serratia sp. & - & ++ & + & - & - & - & - & - & - & + & - & - \\
\hline IM3 & Sphingobacterium sp. & - & +++ & - & - & - & - & - & - & - & + & - & - \\
\hline IM4 & Serratia sp. & +++ & - & + & - & - & - & - & - & - & - & - & + \\
\hline IM5 & Pseudomonas fluorescens & +++ & + & + & - & - & - & - & - & - & + & - & - \\
\hline IM6 & Arthrobacter sp. R4 & ++ & - & - & - & - & - & - & - & - & ++ & - & - \\
\hline IM7 & Obesumbacterium proteus 511 & - & \pm & - & - & - & - & - & - & - & + & - & + \\
\hline IM8 & Serratia proteamaculans DSM4543 & - & - & + & - & - & - & - & - & - & + & - & \pm \\
\hline IM9 & $N D$ & - & +++ & - & - & - & - & - & - & - & \pm & - & + \\
\hline IM10 & Arthrobacter sp. R-36193 & +++ & + & + & - & - & - & - & - & - & - & - & ++ \\
\hline IM11 & Arthrobacter sp. & + & \pm & - & - & - & - & - & - & - & + & - & - \\
\hline IM12 & $\begin{array}{l}\text { Pseudomonas fluorescens LMG } \\
14576\end{array}$ & +++ & +++ & - & - & - & - & - & - & - & \pm & - & \pm \\
\hline IM13 & Myroides sp. IT-2012 & - & - & - & - & - & - & - & + & - & - & - & - \\
\hline IM14 & Serratia sp. a101-87 & +++ & ++ & - & - & - & - & - & - & ++ & - & \pm & ++ \\
\hline IM15 & Pseudomonas putida & +++ & - & - & - & - & - & - & - & - & - & + & - \\
\hline IM16 & Serratia sp. & +++ & - & + & - & - & - & - & - & ++ & \pm & - & ++ \\
\hline IM17 & Stenotrophomonas sp. DIC6JA & +++ & + & - & - & - & - & - & - & - & - & - & + \\
\hline IM18 & Comamonas sp. BM-9_6 & - & ++ & - & - & - & - & - & - & - & - & - & - \\
\hline IM19 & Stenotrophomonas sp. & +++ & +++ & - & - & - & - & - & - & - & - & - & + \\
\hline
\end{tabular}

Symbols: \pm , zone $<1 \mathrm{~mm} ;+$, zone 1 to $3 \mathrm{~mm} ;++$, zone 3 to $5 \mathrm{~mm} ;+++$, zone $>5 \mathrm{~mm}$. *Xanthan lyase activity was tested in liquid MSM with xanthan as a sole carbon source. 
Table 3. Antimicrobial and hemolytic activity of heterotrophic bacteria isolated from the Gallery with the drawings in Magura Cave

\begin{tabular}{|c|c|c|c|c|c|c|}
\hline \multirow{2}{*}{ Isolate code } & \multirow{2}{*}{$\begin{array}{l}\text { Strains referred to the nearest } \\
16 \mathrm{~S} \text { sequence identity }\end{array}$} & \multicolumn{4}{|c|}{ Inhibition zone (mm) } & \multirow{2}{*}{ Hemolytic activity (mm) } \\
\hline & & B. subtilis & X. oryzae & P. aeruginosa & R. mucilaginosa & \\
\hline B1 & Enterobacter sp. 2B1C & - & - & - & - & - \\
\hline B2 & Pseudomonas fragi & - & - & 8 & - & W \\
\hline B3 & $\begin{array}{l}\text { Pseudomonas fluorescens } \\
15834\end{array}$ & - & 2 & 20 & 16 & W \\
\hline B4 & $N D$ & - & - & 8 & - & W \\
\hline B5 & Serratia sp. & - & 4 & - & - & 3.0 \\
\hline B6 & Enterobacter asburiae JCM6051 & - & - & - & - & - \\
\hline B7 & Sphingobacterium sp. & - & 10 & 10 & - & w \\
\hline B8 & Pseudomonas sp. & - & - & - & 10 & 2.0 \\
\hline B9 & Bacillus safensis KTT-25 & - & - & - & - & - \\
\hline B11 & Enterobacter sp. & - & - & - & - & w \\
\hline B13 & Sphingobacterium sp. & - & - & 12 & 6 & - \\
\hline B14 & Serratia sp. L0305 & - & - & 10 & 6 & w \\
\hline B16 & Serratia sp. & - & - & 10 & - & 2.0 \\
\hline B17 & Micrococcus luteus CJ-G-TSA7 & - & - & - & 2 & W \\
\hline B18 & Serratia sp. & - & - & - & - & w \\
\hline B19 & $N D$ & - & - & 8 & - & 2.0 \\
\hline B20 & Serratia sp. & - & - & - & - & w \\
\hline CB9 & Micrococcus luteus CUB12 & - & - & - & - & - \\
\hline CB11 & Serratia sp. & - & - & - & - & W \\
\hline CB12 & Bacillus flexus SL21 & - & - & - & - & w \\
\hline CB13 & $N D$ & - & - & 8 & - & - \\
\hline CB15 & Sphingobacterium sp. Ag8 & - & - & 10 & - & w \\
\hline CB16 & $\begin{array}{l}\text { Bacillus amyloliquefaciens } \\
\text { ZP0308 }\end{array}$ & - & - & 10 & - & 3.0 \\
\hline G5 & Acinetobacter sp. CJ-S-PYD4 & - & - & - & 4 & - \\
\hline G7 & Pseudomonas sp. & - & - & - & 8 & 3.0 \\
\hline IM1 & Serratia sp. 136-2 & - & - & 10 & 2 & - \\
\hline IM2 & Serratia sp. & - & - & - & 2 & w \\
\hline IM3 & Sphingobacterium sp. & - & - & - & - & 3.0 \\
\hline IM4 & Serratia sp. & - & - & 12 & - & w \\
\hline IM5 & Pseudomonas fluorescens & - & - & 12 & 16 & 3.0 \\
\hline IM6 & Arthrobacter sp. R4 & - & - & 4 & 6 & 3.0 \\
\hline IM7 & Obesumbacterium proteus 511 & - & - & 10 & 16 & 4.0 \\
\hline IM8 & $\begin{array}{l}\text { Serratia proteamaculans } \\
\text { DSM4543 }\end{array}$ & - & - & 14 & 2 & - \\
\hline IM9 & $N D$ & - & - & 14 & 4 & W \\
\hline IM10 & Arthrobacter sp. R-36193 & - & - & 6 & 4 & - \\
\hline IM11 & Arthrobacter sp. & - & - & - & - & 2.0 \\
\hline IM12 & $\begin{array}{l}\text { Pseudomonas fluorescens LMG } \\
14576\end{array}$ & - & - & - & 16 & W \\
\hline IM13 & Myroides sp. IT-2012 & - & - & - & 8 & W \\
\hline IM14 & Serratia sp. a101-87 & - & - & - & 8 & 3.0 \\
\hline IM15 & Pseudomonas putida & 16 & 6 & - & 8 & w \\
\hline IM16 & Serratia sp. & 16 & 2 & $12-14$ & 10 & 2.0 \\
\hline IM17 & Stenotrophomonas sp. DIC6JA & - & - & $12-14$ & - & 2.0 \\
\hline IM18 & Comamonas sp. BM-9_6 & 20 & 10 & $12-14$ & 8 & 3.5 \\
\hline IM19 & Stenotrophomonas sp. & - & - & $12-14$ & 2 & W \\
\hline IM20 & Pseudomonas plecoglossicida & 20 & 10 & 4 & 10 & 3.5 \\
\hline IM21 & Pseudomonas sp. & - & - & - & - & 3.0 \\
\hline
\end{tabular}

Symbols: -, no zone observed; clear inhibition zones minus $6 \mathrm{~mm}$ diameter of well are indicated. W, weak clear zone $\leq 1 \mathrm{~mm}$ 
Acinetobacter, and Enterobacteriaceae family could be potential pathogens, perhaps translocated into the cave by animals and human visitors (Northup \& Lavoie, 2001; Campbell et al., 2011). Bastian et al. (2009) reported that the Lascaux Cave is a reservoir of potential pathogenic bacteria. Pathogenic bacteria frequently isolated from caves are Escherichia coli, Staphylococcus aureus, and species of Pseudomonas, Sphingomonas, and Alcaligenes (Ikner et al., 2007). Lavoie \& Northup (2006) considered Bacillus spp., E. coli, and S. aureus as indicators of human impact in the caves.

We found that most of the isolated heterotrophic bacteria from Magura Cave (about 69\%) are psychrotolerant (psychrotrophic) by the highest growth rate observed between 20 and $30^{\circ} \mathrm{C}$. Similarly, Khizhnyak at al. (2003) reported that the amount of typically mesophilic strains in some Siberian cavities is many times lower than psychrophilic and psychrotolerant strains. According to Gounot (1994), all autochthonous bacteria in caves situated in temperate regions are psychrotrophic, growing well at $20^{\circ} \mathrm{C}$ and above.

Psychrophilic and psychrotrophic microorganisms have developed a complex range of structural and functional adaptations to thrive successfully in low temperature environments (Margesin \& Miteva, 2011). Poor levels of nutrients in the caves promote the competition of microorganisms by production of high amounts of exopolymeric substances, enzymes and antimicrobial metabolites that is one of the strategies for their survival (Smalås et al., 2000; Burgess et al., 1999; Slattery et al., 2001). It is known that heterotrophic bacteria and their enzymes play a key role in the processes of recycling, decomposition and mineralization of a wide spectrum of organic polymers in different environments (Munster \& De Haan, 1998). Patterns of enzyme activities can be used to define the composition of organic matter in the ecosystems (Boschker \& Cappenberg, 1998). Heterotrophic bacteria isolated from Magura Cave showed varied enzymatic patterns, which expressed different degrees of nutritional and ecological versatility.

Only few reports have been published on hydrolytic enzymes production by culturable bacteria isolated from subterranean environments including caves. Martinez et al. (2011) considered that measuring extracellular enzyme activity is one way to measure microbial responses to nutrient availability. The authors have assayed alanine aminopeptidase, phosphatase, and $\beta$-glucosidase activities in samples from three limestone caves in New Mexico and have determined whether microorganisms are nitrogen, carbon or phosphate limited. Similar to our results, Khizhnyak et al. (2003) reported that cultures from several Siberian caves synthesized more exogenous proteases compared to amylolytic enzymes because there were no natural sources of starch there. Rashid et al. (2001) reported for a low-temperature lipase produced by psychrotrophic Pseudomonas sp. isolated from subterranean environments. Psychrotolerant heterotrophic bacteria isolated from Magura Cave at given conditions could be attractive producers of valuable cold-tolerant enzymes with a potential for application in various industries - in food and dairy industry, textile industry, brewing and wine industry, laundry, etc. High activity of cold-active enzymes at low and moderate temperatures offers potential economic benefits through substantial energy savings in large-scale processes (Russell, 1998; Gerday et al., 2000; Cavicchioli et al., 2011). Our study is a first investigation of production of RNAse, urease, phytase, polygalacturonase, and xanthan lyase enzymes by psychrophilic/psychrotolerant microorganisms isolated from caves. As promising producers of coldtolerant enzymes could be accepted: B2 (Pseudomonas fragi) and CB9 (Micrococcus luteus) - for xanthan lyase and phytase; B16 (Serratia sp.) - for lipase and urease; B17 (Micrococcus luteus) - for urease; CB15 (Sphingobacterium sp. Ag8) - for protease, phytase and $\beta$-glucosidase; CB16 (B. amyloliquefaciens) - for protease, amylase and RNAse; Serratia strains IM14 and IM16 - for polygalacturonase and $\beta$-glucosidase.

Nowadays, there is a need for new antimicrobial agents due to the increase in drug resistance in many common bacterial pathogens, and the emergence of new infections (Davis \& Webb, 1998). Cold-adapted microorganisms have been recognized as valuable sources of novel bioproducts including antimicrobial metabolites (Sanchez et al., 2009). Information about antimicrobial activity of bacteria isolated from karstic caves is rare, related mainly to Actinobacteria (Kim et al., 1998; Yucel \& Yamac, 2010). Kim et al. (1998) have shown that up to $78 \%$ of Actinobacteria isolated from cave soils in Korea have been antagonistic to plant pathogenic fungi. About 62\% of Actinobacteria isolated from rock wall and speleothems surfaces, and soil samples of 19 karstic caves in Turkey exhibited antimicrobial activity against a panel of four bacteria, two yeasts and four filamentous fungi (Yucel \& Yamac, 2010). We selected several bacterial isolates from Magura Cave as promising producers of antimicrobial compounds such as B3 (P. fluorescens), B7, B13 (Sphingobacterium sp.), IM15, IM18 (Comamonas sp.), IM19 (Stenotrophomonas sp.), and IM20 (P. plecoglossicida). Isolates B5, B7, IM15, IM18, and IM20 exhibiting antibiotic activity against $X$. oryzae are prospective strains for future application in the agriculture for plant protection.

Most of heterotrophic bacteria isolated from Magura Cave exhibited hemolytic activity on blood agar plates. Surface activity is often accomplished by hemolysis and sometimes by antimicrobial activity, and both activity assays have been used to search for surfactant-producing bacteria. Due to their amphiphilic character, surfactants often induce hemolysis at a given concentration (Vinardell \& Infante, 1999). Hemolysis, observed on blood agar plates, has been widely used to screen surfactant-producing microorganisms (Moran et al., 2002). Production of biosurfactants is of biotechnological importance due to their potential application in different industries - in food, cosmetics, pharmaceutical, agricultural, petrochemical industries, etc. (Banat et al., 2010). The search for different types of biosurfactants is important since their use in industry requires 
different physicochemical properties. Bacillus, Pseudomonas, and Serratia strains are well-known producers of lipopeptide biosurfactants having important biotechnological applications, whereas knowledge about Comamonas, Sphingobacterium or Stenotrophomonas as producers of surface active substances is rare (Banat et al., 2010; BurgosDiaz et al., 2011). Among microorganisms isolated from caves, only Actinobacteria have been screened for biosurfactant production (Bottos, 2004). Our study is a first report about the hemolytic activity of heterotrophic cave bacteria. Eight of bacterial strains isolated from Magura Cave (B5, CB16, IM5, IM6, IM7, IM16, IM18, and IM20) expressed high hemolytic activity together with antimicrobial activity and could be suggested as prospective producers of biosurfactants.

In conclusion, our study represents a first report on microbial diversity of a cave in Bulgaria. The results obtained showed that psychrotolerant aerobic culturable bacteria isolated from karstic Magura Cave could serve as a source of industrially important enzymes and bioactive secondary metabolites.

\section{ACKNOWLEDGEMENTS}

The authors are grateful to the National Fund for Scientific Research for financial support of this work (Contract DDVU 02/73). The authors thank Prof. V. Groudeva and the research team from Faculty of Biology at Sofia University for their work on collection of samples from Magura Cave and isolation of the strains No 1-25; the archaeologist Sara Tatarova (Historical Museum in Belogradchik town) and Speleo Club Helictit for valuable contributions during sampling in Magura Cave.

\section{REFERENCES}

Allemand L. \& Bahn P.G., 2005 - Best way to protect rock art is to leave it alone. Nature, 433: 800. http://dx.doi.org/10.1038/433800c

Altschul S.F., Gish W., Miller W., Myers E.W. \& Lipman D.J., 1990 - Basic local alignment search tool. Journal of Molecular Biology, 215: 403-410. http://dx.doi.org/10.1016/S0022-2836(05)80360-2

Bae H.D., Yanke L.J., Cheng K.-J. \& Selinger L.B., 1999 - A novel staining method for detecting phytase activity. Journal of Microbiological Methods, 39: 17-22. http://dx.doi.org/10.1016/S0167-7012(99)00096-2

Banat, I.M., Franzetti A., Gandolfi I., Bestetti G., Martinotti, M.G., Fracchia L., Smyth T.J. \& Marchant R., 2010 - Microbial biosurfactants production, applications and future potential. Applied Microbiology and Biotechnology, 87: 427-444.

http://dx.doi.org/10.1007/s00253-010-2589-0

Barton H.A. \& Northup D.E., 2007 - Geomicrobiology in cave environments: past, current and future perspectives. Journal of Caves \& Karst Studies, 69: 163-178.

Bastian F., Alabouvette C. \& Saiz-Jimenez C., 2009 - Bacteria and free-living amoeba in the Lascaux Cave. Research in Microbiology, 160: 38-40. http://dx.doi.org/10.1016/j.resmic.2008.10.001
Boschker H.T.S. \& Cappenberg T.E., 1998 Patterns of extracellular enzyme activities in littoral sediments of Lake Gooimeer, The Netherlands. FEMS Microbiology and Ecology, 25: 79-86. http://dx.doi.org/10.1111/j.1574-6941.1998.tb00461.x

Bottos E., 2004 - Screening for Biosurfactant Production in Actinomycetes Isolated from Cave and Forest Soils. (Student Poster Presentation).

Burgess J.G., Jordan E.M., Bregu M., MearnsSpragg A. \& Boyd K.G., 1999 - Microbial antagonism: A neglected avenue of natural products research. Journal of Biotechnology, 70: 27-32. http:/ / dx.doi.org/10.1016/S0168-1656(99)00054-1

Burgos-Diaz C., Pons R., Espuny M.J., Aranda F.J., Tereul J.A., Manresa A., Ortiz A. \& Marqués A.M., 2011 - Isolation and partial characterization of a biosurfactant mixture produced by Sphingobacterium sp. isolated from soil. Journal of Colloid and Interface Science, 361: 195-204.

http://dx.doi.org/10.1016/j.jcis.2011.05.054

Cabeza M.S., Baca F.L., Puntes E.M., Loto F., Baigorí M.D. \& Morata V.I., 2011 - Selection of psychrotolerant microorganisms producing cold-active pectinases for biotechnological processes at low temperature. Food Technology \& Biotechnology, 49: 187-195.

Campbell J.W., Watson A., Watson C., Ball H. \& Pirkle R., 2011 - Escherichia coli, other coliform, and environmental chemoheterotrophic bacteria in isolated water pools from six caves in northern Alabama and northwestern Georgia. Journal of Cave and Karst Studies, 73: 75-82. http://dx.doi.org/10.4311/jcks2009mb0131

Cañaveras J.C., Sanchez-Moral S., Sloer V. \& SaizJimenez C., 2001 - Microorganisms and microbially induced fabrics in cave walls. Geomicrobiological Journal, 18: 223-240.

http://dx.doi.org/10.1080/01490450152467769

Castanier S., Le Méteyer-Levrel G. \& and Martire L., 2000 - Bacterial roles in the precipitation of carbonate minerals. In: Riding R.E. \& Awramik S.M. (Eds.), Microbial sediments. Heidelberg: Springer: 32-39.

Cavicchioli R., Charlton T., Ertan H., Mohd Omar S., Siddiqui K.S. \& Williams T.J., 2011 - Biotechnological uses of enzymes from psychrophiles. Microbial Biotechnology, 4: 449-460.

http://dx.doi.org/10.1111/j.1751-7915.2011.00258.x

Chelius M.K. \& Moore J.C., 2004 - Molecularphylogenetic analysis of archaea and bacteria in Wind Cave, South Dakota. Geomicrobiology Journal, 21: 123-134. http://dx.doi.org/10.1080/01490450490266389

Cotty P.J., Cleveland T.E., Brown R.L. \& Mellon J.E., 1990 - Variation in polygalacturonase production among Aspergillus flavus isolates. Applied \& Environmental Microbiology, 56: 3885-3887.

Davis J. \& Webb V., 1998 - Antibiotic resistance in bacteria. In: Krause R.M. (Ed.), Emerging infections: biomedical research reports. New York: Academic Press: 239-273. http:/ /dx.doi.org/10.1016/S1874-5326(07)80032-9

Dhawale M.R., Wilson J.J., Khachatourians G.G. \& Ingledew W.M., 1982 - Improved method for detection of starch hydrolysis. Applied \& Environmental Microbiology, 44: 747-750.

Engel A.S., 2010 - Microbial diversity of cave ecosystems. In: Loy, A., Mandl, M. \& Barton, L.L. (Eds.), Geomicrobiology: Molecular and Environmental Perspective. New York: Springer: 219-238.

Fox J. L., 2008 - Some say Lascaux Cave paintings are in microbial "crisis" mode. Microbe, 3: 110-112. 
Gerday C., Aittaleb M., Bentahir M., Chessa J.P., Claverie P., Collins T., D'Amico S., Dumont J., Garsoux G., Georlette D., Hoyoux A., Lonhienne T., Meuwis M.A. \& Feller G., 2000 - Cold-adapted enzymes: From fundamentals to biotechnology. Trends in Biotechnology, 18: 103-107. http://dx.doi.org/10.1016/S0167-7799(99)01413-4

Gerič B., Pipan T. \& Mulec J., 2004 - Diversity of culturable bacteria and meiofauna in the epikarst of Škocjanske jame Caves (Slovenia). Acta carsologica, 33: 301-309.

Gounot A.M., 1994 - Microbial ecology of groundwaters. In: Gibert J., Danielopol D.L., \& Stanford J.A. (Eds). Groundwater ecology. San Diego, CA: Academic Press: 189-215.

Groth I. \& Saiz-Jimenez C., 1999 - Actinomycetes in hypogean environments. Geomicrobiology Journal, 16: 1-8. http://dx.doi.org/10.1080/014904599270703

Groth I., Schumann P., Laiz L., Sanchez-Moral S., Cañaveras J.C. \& Saiz-Jimenez C., 2001 Geomicrobiological study of the Grotta dei Cervi, Porto Badisco, Italy. Geomicrobiology Journal, 18: 241-258. http://dx.doi.org/10.1080/01490450152467778

Groth I., Vettermann R., Schuetze B. et al., 1999 Actinomycetes in karstic caves of northern Spain (Altamira and Tito Bustillo). Journal of Microbiological Methods, 36: 115-1220.

http://dx.doi.org/10.1016/S0167-7012(99)00016-0

Ikner L.A., Toomey R.S., Nolan G., Neilson J.W., Pryor B.M. \& Maier R.M., 2007 - Culturable microbial diversity and the impact of tourism in Kartchner Caverns, Arizona. Microbial Ecology, 53: 30-42.

http://dx.doi.org/10.1007/s00248-006-9135-8

Jurado V., Laiz L., Rodriguez-Nava V., Boiron P., Hermosin B., Sanchez-Moral S. \& Saiz-Jimenez C., 2010 - Pathogenic microorganisms in caves. International Journal of Speleology, 39: 15-21. http://dx.doi.org/10.5038/1827-806X.39.1.2

Khizhnyak S.V., Tausheva I.V., Berezikova A.A., Nesterenko E.V. \& Rogozin D.Y., 2003 - Psychrophilic and psychrotolerant heterotrophic microorganisms of middle Siberian karst cavities. Russian Journal of Ecology, 34: 231-235. http://dx.doi.org/10.1023/A:1024537513439

Kim B.S., Lee J.Y. \& Hwang B.K., 1998 - Diversity of actinomycetes antagonistic to plant pathogenic fungi in cave and sea-mud soils of Korea. Journal of Microbiology, 36: 86-92.

Lavoie K.H. \& Northup D.E., 2006 - Bacteria as indicators of human impact in caves. In: Rea G.T. (Ed.), $17^{\text {th }}$ National Cave and Karst Management Symposium, Proceedings. Albany, NY: NICKMS Steering Committee: 40-47.

MacFaddin J. F., 2000 - Biochemical tests for the identification of medical bacteria, 3rd ed. Philadelphia, PA: Lippincott Williams \& Wilkins.

Maidak B.L., Larsen N., McCaughey M.J., Overbeek R., Olsen G.J., Fogel K., Blandy J. \& Woese C.R., 1994 - The Ribosomal Database Project. Nucleic Acids Research, 22: 3485-3487. http://dx.doi.org/10.1093/nar/22.17.3485

Margesin R. \& Miteva V., 2011 - Diversity and ecology of psychrophilic microorganisms. Research in Microbiology, 162: 346-361. http://dx.doi.org/10.1016/j.resmic.2010.12.004

Martinez N.G., Sinsabaugh R.L. \& Northup D.E., 2011 Human Impact on Extracellular Enzyme Activity within Carlsbad Cavern and Lechuguilla and Spider Caves in Carlsbad Caverns National Park, New Mexico.

http://sacnas.confex.com/sacnas/2011/ webprogram/Paper1801.html

Mendes Ferreira A., Clímaco M.C. \& Mendes Faia A., 2001 - The role of non-Saccharomyces species in releasing glycosidic bound fraction of grape aroma components--a preliminary study. Journal of Applied Microbiology, 91: 67-71. http://dx.doi.org/10.1046/ j.1365-2672.2001.01348.x
Moran A.C., Martınez M.A. \& Siñeriz F., 2002 Quantification of surfactin in culture supernatants by hemolytic activity. Biotechnology Letters, 24: 177-180. http://dx.doi.org/10.1023/A:1014140820207

Morita R.Y., 1975 - Psychrophilic bacteria. Bacteriological Reviews, 39: 144-167.

Mulec J., Krištůfek V. \& Chroňáková A., 2012 Comparative microbial sampling from eutrophic caves in Slovenia and Slovakia using $\operatorname{RIDA}^{\circledR}$ COUNT test kits. International Journal of Speleology, 41: 1-8. http://dx.doi.org/10.5038/1827-806X.41.1.1

Munster U. \& De Haan, H., 1998 - The role of microbial extracellular enzymes in the transformation of dissolved organic matter in humic waters. Ecology Studies, 133: 199-257.

Northup D.E. \& Lavoie K.H., 2001 - Geomicrobiology of caves: A review. Geomicrobiology Journal, 18: 199222. http://dx.doi.org/10.1080/01490450152467750

Rashid N., Yuji S., Satoshi E., Haruyuki A. \& Tadayuki I., 2001 - Low-temperature lipase from psychrotrophic Pseudomonas sp. strain KB700A. Applied \& Environmental Microbiology, 67: 4064-4069. http://dx.doi.org/10.1128/AEM.67.9.4064-4069.2001

Russell N.J., 1998 - Molecular adaptations in psychrophilic bacteria: potential for biotechnological applications. In: Scheper T. (Ed.), Advances in Biochemical Engineering/ Biotechnology. Berlin: Springer, 61: 1-21.

Sanchez L.A., Gomez F.F. \& Delgado O.D., 2009 Cold-adapted microorganisms as a source of new antimicrobials. Extremophiles, 13: 111-120. http://dx.doi.org/10.1007/s00792-008-0203-5

Schabereiter-Gurtner C., Saiz-Jimenez C., Piñar G., Lubitz W. \& Rölleke S., 2002a - Altamira cave Paleolithic paintings harbor partly unknown bacterial communities. FEMS Microbiology Letters, 211: 7-11. http://dx.doi.org/10.1111/j.1574-6968.2002.tb11195.x

Schabereiter-Gurtner C., Saiz-Jimenez C., Piñar G., Lubitz W. \& Rölleke S., 2002b - Culture-independent analyses of bacterial communities on paleolithic paintings and surrounding rock walls in karstic caves (Altamira, Tito Bustillo, La Garma and Llonin). Coalition Newsletter, 5: 7-10.

Slattery M., Rajbhandari I. \& Wesson K., 2001 Competition mediated antibiotic induction in the marine bacterium Streptomyces tenjimariensis. Microbial Ecology, 41: 90-96.

Smalås A.O., Leiros H.K., Os V. \& Willassen N.P., 2000 - Cold adapted enzymes. Biotechnology Annual Review, 6: 1-57. http://dx.doi.org/10.1016/S1387-2656(00)06018-X

Smilbert R.M., 1994 - Phenotypic characterization. In: Gerhardt P., Murray R.E.G., Wood W.A. \& Krieg N.R. (Eds.), Methods for general and molecular microbiology. Washington: American Society for Microbiology: 611-654.

Stoychev T., 1994 - Eneolithic paintings from Magoura cave, Bulgaria. (in Bulgarian; English summary). Annuary of Department of Architecture NBU, 1: 307-320.

Stoytchev T., 1995 - Newfound prehistorical imiges and signs in Magoura cave and Tzarevetz cave complex (in Bulgarian). Architecture Discoveries and Excavations during 1994. Smolian: 13-15.

Swofford D.L., 2002 - PAUP*: Phylogenetic Analysis Using Parsimony (* and other methods), version 4. Sunderland, MA: Sinauer Associates.

Teather R.M. \& Wood P.J., 1982 - Use of Congo redpolysaccharide interaction in enumeration and characterization of cellulohydrolytic bacteria from the bovine rumen. Applied and Environmental Microbiology, 53: 41-46.

Thompson J.D., Gibson T.J., Plewniak F., Jeanmougin F. \& Higgins D.G., 1997 - The CLUSTAL X windows interface: Flexible strategies for multiple sequence alignment aided by quality analysis tools. Nucleic Acids Research, 25: 4876-4882. http://dx.doi.org/10.1093/nar/25.24.4876 
Urzì C., De Leo F., Bruno L. \& Albertano P., 2010 Microbial diversity in Paleolithic caves: A study case on the phototrophic biofilms of the Cave of Bats (Zuheros, Spain). Microbial Ecology, 60: 116-129. http://dx.doi.org/10.1007/s00248-010-9710-x

Van den Burg B., 2003 - Extremophiles as a source for novel enzymes. Current Opinion in Microbiology, 6: 213-218. http://dx.doi.org/10.1016/S1369-5274(03)00060-2

Vinardell M.P. \& Infante M.R., 1999 - The relationship between the chain length of non-ionic surfactants and their hemolytic action on human erythrocytes. Comparative Biochemistry \& Physiology Part C, 124: 117-120.
Weisburg W.G., Barns S.M., Pelletier D.A. \& Lane D.J., 1991 - 16S ribosomal DNA amplification for phylogenetic study. Journal of Bacteriology, 173: 697-703.

Yucel S. \& Yamac M., 2010 - Selection of Streptomycetes isolates from Turkish karstic caves against antibiotic resistant microorganisms. Pakistan Journal of Pharmaceutical Sciences, 23: 1-6.

Zhou J.P., Gu Y.Q., Zou C.S., Mo M.H., 2007 - Phylogenetic diversity of bacteria in an earth-vave in Guizhou Province, Southwest of China. Journal of Microbiology, 45: 105-112. 